\section{Kidney Blood Pressure Research}

Kidney Blood Press Res 2012;36:18-25

DOI: $10.1159 / 000339023$

Published online: July 03, 2012

Accepted: May 31, 2012

\title{
A Comparison of the Antihypertensive and Anti-Inflammatory Effects of Aliskiren and Ramipril Add-On Therapy in Peritoneal Dialysis Patients - A Pilot Open Label Study
}

\author{
Agnieszka Makówka Magdalena Olejniczak-Fortak Michał Nowicki \\ Department of Nephrology, Hypertension and Kidney Transplantation, Medical University of Łódź, \\ Poland
}

\author{
Key Words \\ Arterial hypertension $\bullet$ Peritoneal dialysis $•$ Aliskiren $\bullet$ Ramipril $\bullet$ Inflammation
}

\begin{abstract}
Most hypertensive dialysis patients are currently treated with angiotensin converting enzyme inhibitors (ACEI) and angiotensin receptor blockers (ARB). Aliskiren, the direct renin inhibitor, has not been specifically studied in peritoneal dialysis patients. The aim of the study was to compare hypotensive effects of aliskiren and ramipril and their influence on serum potassium and inflammatory parameters in hypertensive peritoneal dialysis patients. Eighteen hypertensive patients on chronic peritoneal dialysis were enrolled in an open-label comparative fixed-order study. The patients had been off RAAS blocking drugs for $\geq 4$ weeks prior to an inclusion. At each of 3 study visits (baseline and after each of the treatment periods) blood pressure, serum lipids, potassium, renin, aldosterone, C-reactive protein (CRP) and monocyte chemotactic protein-1 (MCP-1) were measured. After the baseline visit aliskiren was started $(150 \mathrm{mg} / \mathrm{d})$ and after 12 weeks replaced with ramipril $(5 \mathrm{mg} / \mathrm{d})$ for the next 12 weeks. Blood pressure was $142 / 88 \pm 15 / 11 \mathrm{mmHg}$ at baseline, $137 / 84 \pm 10 / 8 \mathrm{mmHg}$ after aliskiren (ns) and 126/81 $\pm 11 / 7$ $\mathrm{mmHg}$ after ramipril ( $p<0.05$ vs baseline and aliskiren). No incidents of hyperkalemia were observed. Plasma renin concentration increased significantly during aliskiren treatment compared to ramipril $(227,6 \pm 844$ vs $58,3 \pm 765 \mathrm{pg} / \mathrm{mL})$. CRP was similar after both therapies $(8,8 \pm 34$ vs $8,4 \pm 32 \mu \mathrm{g} / \mathrm{mL})$ but MCP- 1 concentration was significantly lower after aliskiren than after ramipril $(294,0 \pm 172,6$ vs $358,9 \pm 183,3 \mathrm{pg} / \mathrm{mL})$. Aliskiren $150 \mathrm{mg} /$ day decreases blood pressure less effectively than ramipril $5 \mathrm{mg} /$ day in peritoneal dialysis patients. It does not influence serum potassium. The decrease of MCP-1 concentration after aliskiren treatment may provide an indirect evidence for its blood pressure independent cardioprotective and anti-inflammatory effects.
\end{abstract}




\section{Kidney \\ Blood Pressure Research}

Kidney Blood Press Res 2012;36:18-25

\begin{tabular}{l|l} 
DOI: $10.1159 / 000339023$ & (c) 2012 S. Karger AG, Basel
\end{tabular}

Published online: July 03, 2012

www.karger.com/kbr

Makówka/Olejniczak-Fortak/Nowicki: Aliskiren in Peritoneal Dialysis Patients

\section{Introduction}

High blood pressure (BP) increases the risk of cardiovascular complications in both the general population and chronic dialysis patients [1,2]. Arterial hypertension (HTN) is diagnosed in up to $80 \%$ of peritoneal dialysis patients [3] and its cardiovascular consequences such as left ventricular hypertrophy are even more common among peritoneal dialysis than hemodialysis patients [4]. Due to the complex pathogenesis of HTN in dialysis patients involving both the neurohormonal activation and chronic volume expansion the resistance to antihypertensive treatment is frequently observed [5]. One of the key pathogenic factors in dialysis patients with HTN is the increased activity of the renin-angiotensin-aldosterone system (RAAS) [5, 6]. Therefore the drugs that inhibit the RAAS such as angiotensinconverting enzyme inhibitors (ACEI) or angiotensin receptor blockers (ARB) are frequently prescribed to dialysis patients [5-8]. Alternative drugs suppressing the RAAS activity such as spironolactone or eplerenone are not recommended in end-stage kidney disease largely due to an increased risk of hyperkalemia [3, 9].

Direct renin inhibitors, which suppress the RAAS in the initial activation stage, are the latest class of antihypertensive drugs that has been commercially available [10]. Aliskiren is currently the only drug from this class. So far several studies have shown that aliskiren effectively decreases blood pressure with the side-effect profile similar to placebo $[8,11$, 12]. Since aliskiren is excreted with bile and does not require dose reduction in case of decreased glomerular filtration rate it could become a preferred drug for the treatment of hypertension in end-stage kidney disease [10]. Furthermore aliskiren decreases the activity of the sympathetic nervous system to a similar extend as ACEIs and ARBs but although all these agents decrease a concentration of angiotensin I and II and aldosterone only aliskiren increases plasma renin concentration with a parallel decrease of its plasma activity $[8,13$, 14].

It has been shown that an increase of RAAS activity could induce a proinflammatory effect and leads to endothelial dysfunction and left ventricular hypertrophy, and thereby may be linked to faster progression of kidney disease $[6,8]$. Some studies showed that the drugs suppressing RAAS such as ACEIs or ARBs may have anti-inflammatory action [15-17]. It was also found that aliskiren may decrease the concentration of inflammatory and antifibrotic factors but the evidence has so far been scarce [18-20].

The aim of our study was to compare a hypotensive effect of the direct renin inhibitor aliskiren and ACEI ramipril in chronic peritoneal dialysis patients. Additionally, we assessed the effect of aliskiren on serum potassium and serum biomarkers of inflammation.

\section{Patients and Methods}

Eighteen hypertensive patients undergoing chronic peritoneal dialysis (12 treated with automated peritoneal dialysis - APD and 6 with continuous ambulatory peritoneal dialysis - CAPD) for more than 6 months (mean 18.1 \pm 22.4 months, median 9.5, range 7-78 months) and in a stable clinical condition (14 M, 4 F; mean $59.4 \pm 12.3$ years, median 61 , range $34-70$ years) ; BMI $27.3 \pm 4.6 \mathrm{~kg} / \mathrm{m}^{2}$, median 26 , range 19 $34 \mathrm{~kg} / \mathrm{m}^{2}$ ) were enrolled into a pilot open-label comparative study with fixed-order design. All patients had preserved residual diuresis and a target total weekly $\mathrm{Kt} / \mathrm{V}_{\text {urea }}$ of $>1,7$. Mean time from the diagnosis of kidney disease to end-stage kidney disease was 45.9 \pm 35.0 months (median 32, range 15-107 months). In all patients the peritoneal dialysis was the first form of renal replacement therapy. Kidney disease was caused by arterial hypertension in 4 patients, chronic glomerulonephritis ( 5 patients), diabetic nephropathy ( 3 patients), tubulointerstitial nephritis ( 2 patients), adult polycystic kidney disease (1 person), and unknown in 3 patients. All patients had been treated for hypertension for at least 3 months and BP had been satisfactory controlled (systolic blood pressure $<150 \mathrm{mmHg}$ ). Most were on a combination antihypertensive therapy including calcium antagonists (14 patients), betablockers (12 patients) and centrally acting sympatholytics (9 patients) (mean number of antihypertensive drugs $2.5 \pm 0.7$ ). The patients had been off any drugs that directly inhibit RAAS for at least 4 weeks before an enrollment. All antihypertensive drugs used at the time of the qualification to the study were continued in unmodified doses throughout the whole duration of the 


\section{Kidney Blood Pressure Research}

\begin{tabular}{|c|c|}
\hline Kidney Blood Press Res 2 & \\
\hline $\begin{array}{l}\text { DOI: } 10.1159 / 000339023 \\
\text { Published online: July 03, } 2012\end{array}$ & $\begin{array}{l}\text { (c) } 2012 \text { S. Karger AG, Basel } \\
\text { www.karger.com/kbr }\end{array}$ \\
\hline
\end{tabular}

Table 1. Baseline clinical and biochemical characteristics of the study group.

\begin{tabular}{ll}
\hline Parameter (units) & mean \pm SD \\
\hline Age (years) & $59 \pm 14$ \\
Body mass index $(\mathrm{kg} / \mathrm{m} 2)$ & $27.1 \pm 4.5$ \\
Time since initiation of PD (months) & $18.1 \pm 22.4$ \\
Systolic blood pressure $(\mathrm{mmHg})$ & $141.7 \pm 15.9$ \\
Diastolic blood pressure $(\mathrm{mmHg})$ & $88.0 \pm 11.2$ \\
Serum total cholesterol $(\mathrm{mmoL} / \mathrm{L})$ & $4.7 \pm 0.9$ \\
Serum triglycerides $(\mathrm{mmoL} / \mathrm{L})$ & $1.9 \pm 1.1$ \\
Serum potassium $(\mathrm{mmoL} / \mathrm{L})$ & $4.68 \pm 0.59$ \\
Serum sodium $(\mathrm{mmoL} / \mathrm{L})$ & $140.1 \pm 3.0$ \\
Serum creatinine $(\mu \mathrm{moL} / \mathrm{L})$ & $658 \pm 289$ \\
Serum urea $(\mathrm{mmoL} / \mathrm{L})$ & $18.2 \pm 5.0$ \\
\hline
\end{tabular}

study treatment. The patients with episodes of hyperkalemia (defined as serum potassium $>6 \mathrm{mmoL} / \mathrm{L}$ ) or acute inflammatory conditions for 3 months prior to the study were excluded. The patients were not receiving any immunosuppressive drugs. Liver and heart insufficiency (NYHA class 2-4) or any vascular incidents in the last 3 months were additional exclusion criteria. The baseline clinical and biochemicalcharacteristics of the study subjects are shown in Table 1. The study protocol was approved by the local Ethics Committee.

During each of the three study visits (baseline and after each of the treatment periods) blood pressure was measured in triplicate and blood was collected for measurements of serum sodium, potassium, creatinine, urea, total cholesterol, triglycerides, renin, aldosterone, C-reactive protein (CRP) and monocyte chemoattractive protein-1 (MCP-1). Following the recruitment visit aliskiren was immediately started in a fixed dose of $150 \mathrm{mg} /$ day once per day for 12 weeks. After that period aliskiren was replaced with ramipril administered in a dose of $5 \mathrm{mg} /$ day for another 12 weeks.

Mean arterial pressure (MAP) was calculated as diastolic blood pressure $+1 / 3$ of systolic - diastolic blood pressure.

Total cholesterol and plasma triglycerides were measured with standard automated laboratory methods, serum sodium and potassium with flame photometry. Serum high-sensitive C-reactive protein and MCP-1 were measured with immunoenzymatic method (Quantikine, R\&D Systems Europe, Ltd., Abington, UK), plasma renin and aldosterone with radioimmunoassay.

Data are shown as mean \pm SD and median and range as appropriate. To assess the differences between the visits ANOVA for repeated measurements and paired t-test or Wilcoxon test for non-normally distributed data were used. Significance was set as $p<0.05$.

\section{Results}

Blood pressure tended to decrease after 12 weeks of aliskiren treatment but the difference did not reach statistical significance ( $\mathrm{p}=0.11$ vs baseline for systolic and mean blood pressure and $\mathrm{p}<0.05$ for diastolic blood pressure). In contrast, after the treatment with ramipril blood pressure significantly decreased ( $\mathrm{p}=0.001$ vs both baseline and aliskiren) (Fig. 1). Serum potassium did not change during the study (Fig. 2) and there were no episodes of hyperkalemia during the whole study (defined as serum potassium $>6 \mathrm{mmoL} / \mathrm{L}$ with or without clinical symptoms). As expected, plasma renin concentration was significantly higher during aliskiren treatment in comparison to baseline and ACEI therapy ( $\mathrm{p}=0.011$ and $\mathrm{p}=0.009$, respectively). There were no changes of aldosterone concentration during the treatment (ns). Serum CRP was similar at all visits, but MCP-I concentration decreased significantly during aliskiren $(\mathrm{p}=0.01)$ but not ramipril treatment (Table 2). Serum urea (18.2 \pm 5.0 at baseline, $17.6 \pm 3.5$ after aliskiren and $18.8 \pm 4.7 \mathrm{mmoL} / \mathrm{L}$ after ramipril) and creatinine was unchanged during the study $(658 \pm 288,690 \pm 278$ and $788.379 \mu \mathrm{moL} / \mathrm{L}$, respectively). There were also no significant changes of total serum cholesterol, serum triglycerides and serum sodium during the study. 


\section{Kidney Blood Pressure Research}

\begin{tabular}{|c|c|}
\hline Kidney Blood Press Res 2 & \\
\hline $\begin{array}{l}\text { DOI: } 10.1159 / 000339023 \\
\text { Published online: July 03, } 2012\end{array}$ & $\begin{array}{l}\text { (c) } 2012 \text { S. Karger AG, Basel } \\
\text { www.karger.com/kbr }\end{array}$ \\
\hline
\end{tabular}

Table 2. Plasma renin, aldosterone, C-reactive protein (CRP) and monocyte chemotactic protein-1 (MCP-1) assessed at baseline and after 12-week treatment with aliskiren and 12-week treatment with ramipril.

\begin{tabular}{llll}
\hline Parameter (units) & Baseline & Aliskiren & Ramipril \\
\hline Renin $(\mathrm{pg} / \mathrm{mL})$ & $76.2 \pm 86.2$ & $227.6 \pm 124.4 *$ & $58.3 \pm 76.5$ \\
Aldosterone $(\mathrm{pg} / \mathrm{mL})$ & $112,5 \pm 60.0$ & $118.6 \pm 51.4$ & $163,9 \pm 118.8$ \\
CRP $(\mathrm{g} / \mathrm{mL})$ & $0.48 \pm 0.41$ & $0.55 \pm 0.42$ & $0.65 \pm 0.47$ \\
MCP-1 (pg/mL) & $473.0 \pm 182.2$ & $294.0 \pm 172.6^{\#}$ & $359 \pm 183.3$ \\
\hline \multicolumn{2}{c}{${ }^{*} \mathrm{p}=0.01$ vs baseline, ${ }^{\#} \mathrm{p}=0.01$ vs baseline } & \\
\hline
\end{tabular}

Fig. 1. Systolic, diastolic and mean blood pressure (MAP) at baseline (visit 1), after 12-week treatment with aliskiren (visit 2) and after 12-week treatment with ramipril (visit 3).

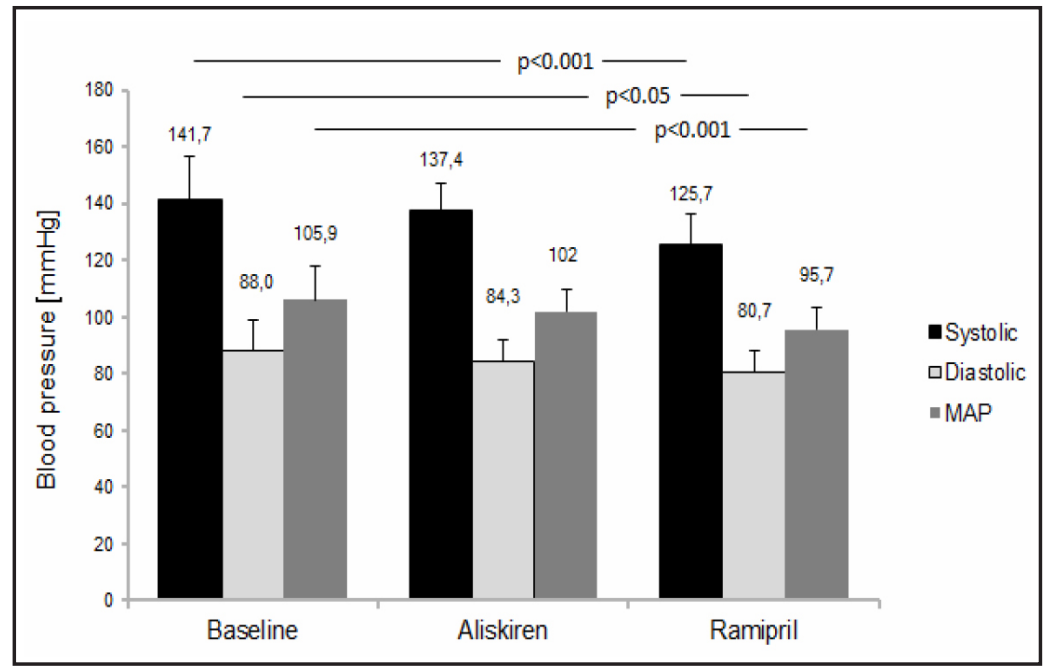

Fig. 2. Serum potassium at baseline (visit 1), after 12-week treatment with aliskiren (visit 2) and after 12-week treatment with ramipril (visit 3).

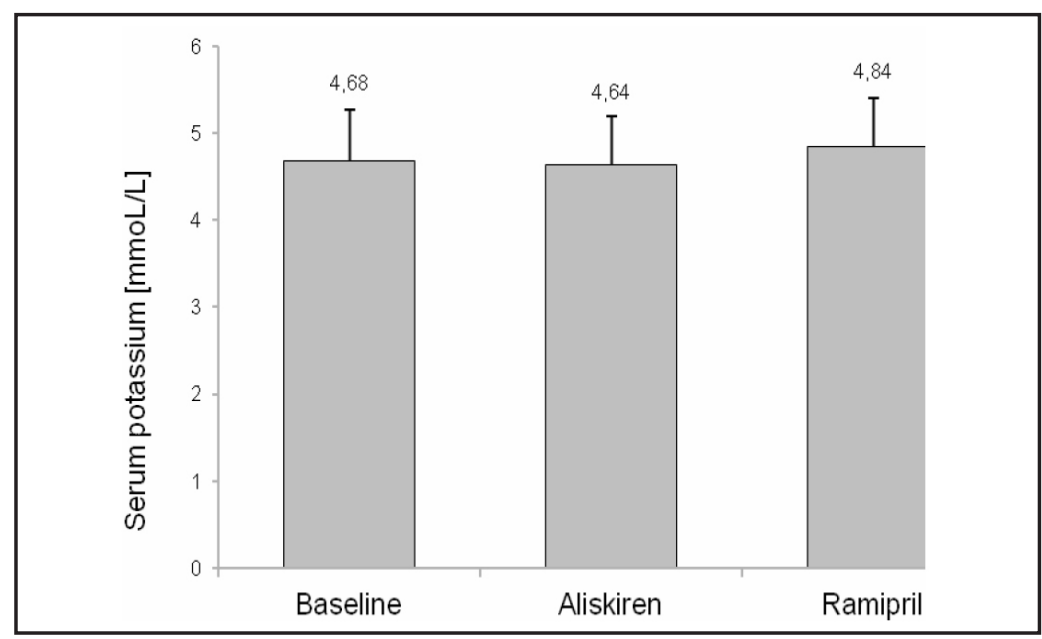

\section{Discussion}

In this study we assessed a hypotensive effect of a direct renin inhibitor aliskiren in chronic peritoneal dialysis patients with arterial hypertension. We showed that the addition of $150 \mathrm{mg} /$ day of aliskiren to an antihypertensive therapy that excluded drugs that inhibit RAAS was safe but the hypotensive effect of the therapy was inferior to ramipril in a dose of $5 \mathrm{mg} /$ day.

Several clinical studies with aliskiren in hypertensive patients without renal impairment showed its satisfactory antihypertensive effects [6, 11, 12, 18, 21-24]. The lack of a significant BP decrease in our study might have been due to several reasons including relatively well-controlled BP with conventional therapy at baseline and the dose of aliskiren 


\section{Kidney
Blood Pressure Research}

Kidney Blood Press Res 2012;36:18-25

\begin{tabular}{l|l} 
DOI: $10.1159 / 000339023$ & (C) 2012 S. Karger AG, Basel
\end{tabular}

Published online: July 03, 2012

www.karger.com/kbr

Makówka/Olejniczak-Fortak/Nowicki: Aliskiren in Peritoneal Dialysis Patients

that was lower than in most other studies [14, 23-25]. Unfortunately the experience with aliskiren in patients with renal impairment has so far been very limited. In an open-label uncontrolled study in a group of 30 hemodialysis patients Morishita et al. [26] found that $150 \mathrm{mg}$ of aliskiren once daily for 8 weeks reduced systolic and diastolic blood pressure by 15.3 and $5.1 \mathrm{mmHg}$, respectively the effect that was larger than in our study ( 5 and $4 \mathrm{mmHg}$, respectively). The study of Siddiqi at al. in patients with chronic kidney disease stage 2-4 proved that a dose of $300 \mathrm{mg} /$ day of aliskiren, i.e. twice larger than in our study, effectively lowered blood pressure along with the reduction of the sympathetic activity [14]. Gradman at al. compared the influence of different daily doses of aliskiren (150 mg, $300 \mathrm{mg}$, and 600 $\mathrm{mg})$ with irbesartan $(150 \mathrm{mg} / 24 \mathrm{~h})$ on arterial pressure in patients with hypertension but without renal impairment [12]. They showed that aliskiren in the dose of $150 \mathrm{mg} / \mathrm{d}$ caused a similar decrease of blood pressure than $150 \mathrm{mg} / 24 \mathrm{~h}$ of irbesartan. Furthermore $300 \mathrm{mg} / \mathrm{d}$ was even more effective but $600 \mathrm{mg} / 24 \mathrm{~h}$ did not give any additional benefits as there were no further lowering of blood pressure and side-effects were more frequent [12]. What is more, Aliskiren Trial in Type 2 Diabetes Using Cardiovascular and Renal Disease Endpoints (ALTITUDE), that aimed to assess the efficiency and safety of adding aliskiren to other RAAS suppressing drug (ACEI or ARB) in diabetic patients with chronic kidney disease has been discontinued due to an increased frequency of side-effects in the group of patients treated with aliskiren (more renal events, hyperkalemia, hypotension, and stroke) [27]. A thorough analysis of this study showed however that most side effects occurred when aliskiren was given in a combination with other RAAS inhibiting drug in a dose of $300 \mathrm{mg} /$ day.

Nevertheless, in our study which compared the hypotensive efficacy of ACEI and aliskiren we observed that ramipril in a daily dose of $5 \mathrm{mg}$ significantly lowered blood pressure in contrast to aliskiren in a dose of $150 \mathrm{mg} /$ day. There were only few studies directly comparing ACEI and aliskiren and none of them included patients with advanced or end-stage kidney disease. Uresin at al. [28] compared a hypotensive efficacy of $300 \mathrm{mg}$ aliskiren with $10 \mathrm{mg}$ ramipril and the combination of these two drugs in a large group of hypertensive patients with type 2 diabetes. They showed that ramipril and aliskiren showed similar antihypertensive effect and combined therapy was more effective. Unlike in ALTITUDE, they did not however note an increased risk of side effects in any of the groups [27,28]. In a study of Andersen et al aliskiren $150 \mathrm{mg} /$ day provided better BP control than ramipril $5 \mathrm{mg} /$ day [18] that is opposite to our results. However that study was performed in patients with arterial hypertension but without chronic kidney disease. It could be speculated that a response to a direct renin inhibitor might be altered in the presence of severely impaired renal function however there has been not enough evidence to support such concept. One has however need to take into account the fact that on the one hand renal failure leads to a stimulation of RAAS and on the other increased renin and prorenin release caused by aliskiren has been found to induce several potentially detrimental effects by the increased generation of angiotensin II in the membrane-bound phase and activation of signal transduction pathways involved in tissue damage, stimulation of profibrotic and inflammatory mediators [29].

It has been well documented that an increase in angiotensin II concentration is not only associated with hypertension, but also leads to release of reactive forms of oxygen and thereby induces oxidative stress $[15,30]$. Chadramonachan at al. observed that RAAS stimulation in the kidneys was associated with an increase in MCP-I and PAI expression. MCP-I is the key factor involved in the activation of macrophages and to the influx of proinflammatory cells, resulting in fibrosis and organ damage. The stimulation of the secretion of the inflammatory markers was caused by the increase of angiotensin II concentration associated with the stimulation of intrarenal RAAS [29]. Similar observations were also made by Proudfoot et al. [15].

In our study we compared the effect of aliskiren and ramipril on serum markers of inflammation. While we were able to demonstrate that both ACEI and aliskiren caused a decrease of MCP-1 only the former reduced its concentration significantly. It is unlikely that such an effect was secondary to a blood pressure decrease since that was significantly 


\section{Kidney
Blood Pressure Research}

Kidney Blood Press Res 2012;36:18-25

\begin{tabular}{l|l} 
DOI: $10.1159 / 000339023$ & C 2012 S. Karger AG, Basel
\end{tabular}

Published online: July 03, 2012

www.karger.com/kbr

larger after ramipril than aliskiren. Our results corroborate those from other studies carried out in different clinical settings i.e. in patients without renal failure and treated with other RAAS blocking agents. Andersen at al. compared the influence of ramipril and aliskiren on inflammatory markers in hypertensive patients without renal function impairment and observed that although both drugs significantly lowered the MCP-1 concentration the decrease was significantly larger after aliskiren [18]. Proudfoot at al. in an experimental study showed that the inhibition of RAAS by two angiotensin II receptor antagonists irbesartan and losartan reduced MCP-1 concentration leading to a suppression of inflammatory markers [15]. Similar results were published by Kato at al. who showed that both ACEI enalapril and ARB candesartan caused the decrease of MCP-1 expression in experimental diabetes but not in non-diabetic animals [16]. Interestingly, MCP-1 reduction correlated with the decrease of proteinuria. The authors drew a conclusion that the activation of RAAS in diabetic nephropathy might have led to an increase in MCP-1 expression. An increase in MCP1 concentration could result from direct activity of angiotensin II through AT1 on the cells generating MCP-1 [16]. That hypothesis was confirmed by Amann at al. who revealed that angiotensin II stimulated the activation of NFKB and the synthesis of MCP-1 by the mesangial cells, which led to inflammatory cell infiltration [31].

Nguyen at al. postulated that an increase in the inflammatory markers was not only dependent on angiotensin II generation but also directly on increased renin production. They also showed that that effect was independent of blood pressure [32]. Tang et al. showed that by adding aliskiren to losartan caused a significant decrease of other inflammatory markers independent of blood pressure [33].

In our study neither of the drugs caused a change of serum CRP, which is a common but unspecific inflammatory marker in the dialysis patients including those treated with peritoneal dialysis [34]. Similar observations on the lack of an effect of aliskiren on CRP were made by Andersen et al. [18]. Karakousis at al. compared the influence of various combinations of hypotensive drugs on serum markers of inflammation and showed that despite a similar hypotensive effect combined aliskiren and valsartan therapy led to a significant decrease of hs-CRP compared to a combination of amlodipine and valsartan [19]. Similar effects were also shown by Muller et al. [8].

The use of a direct renin inhibitor holds promise for more potent blockade of the RAAS system in contrast to ACEI and ARB that do not fully inhibit angiotensin and aldosterone production Moreover the putative direct action of aliskiren on prorenin/renin receptor may explain its action on inflammatory markers that are independent of angiotensin II [35]. Therefore aliskiren has a potential for more effective reduction of inflammation than angiotensin-converting enzyme inhibitors or angiotensin receptor blockers $[6,8]$.

Currently most recommendations for the treatment of arterial hypertension do not apply to dialysis patients. Despite the lack of any evidence from large randomized trials most dialysis patients are treated with the drugs that inhibit RAAS but despite their common use the problem of uncontrolled or resistant hypertension is more frequent in end-stage renal disease than among patients with normal renal function [5-7]. Whether aliskiren may provide additional benefit in these patients is unknown and our results showing its less effective blood-pressure lowering effect than an ACEI on the one hand but a significant decrease of an inflammatory marker MCP-1 by aliskiren and nor by ramipril on the other clearly show that this question may only be answered in large studies with hard endpoints which are however rarely designed and performed in chronic dialysis patients.

\section{Acknowledgements}

Supported by grant of the Medical University of Łódź, Poland, No: 503/5-139-01/50301. 


\section{Kidney \\ Blood Pressure Research}

Kidney Blood Press Res 2012;36:18-25

\begin{tabular}{l|l} 
DOI: $10.1159 / 000339023$ & (C) 2012 S. Karger AG, Basel
\end{tabular}

Published online: July 03, 2012

www.karger.com/kbr

\section{References}

1 Van den Hoogen PC, Feskens EJ, Nagelkerke NJ, Menotti A, Nissinen A, Kromhout D: The relation between blood pressure and mortality due to coronary heart disease among men in different parts of the world. Seven Countries Study Research Group. N Engl J Med 2000;342:1-8.

- Heerspink HJ, Ninoiya T, Zoungas S, de Zeeuw D, Grobbee DE, Jardine MJ, Gallagher M, Roberts MA, Cass A, Neal B, Perkovic V: Effect of lowering blood pressure on cardiovascular events and mortality in patients on dialysis: a systematic review and meta-analysis of randomized controlled trials. Lancet 2009;373:10091015.

-3 Cocchi R, Degli Esposti E, Fabbri A, Lucatello A, Sturani A: Prevalence of hypertension in patients on peritoneal dialysis: results of an Italian multicentre study. Nephrol Dial Transplant 1999;14:1536-1540.

4 Enia G, Mallamaci F, Benedetto FA, Panuccio V, Parlongo S, Cutrupi S, Giacone G, Cottini E, Tripepi G, Malatino LS, Zoccali C: Long-term CAPD patients are volume expanded and display more severe left ventricular hypertrophy than haemodialysis patients. Nephrol Dial Transplant 2001;16:1459-1464.

-5 Agarwal R: Epidemiology of interdialytic ambulatory hypertension and the role of volume excess. Am J Nephrol 2011;34:381-390.

6 Sever PS, Gradman HTN, Azizi M: Managing cardiovascular and renal risk: the potential of direct renin inhibitor. JRAAS 2009;10:65-76.

-7 Tai DJ, Lim TW, James MT, Manns BJ, Tonelli M, Hemmelgarn BR:Alberta Kidney Disease Network. Cardiovascular effects of angiotensin converting enzyme inhibition or angiotensin receptor blockade in hemodialysis: a metaanalysis. Clin J Am Soc Nephrol 2010;5:623-630.

8 Muller DN, Luft FC: Direct renin inhibition with aliskiren in hypertension and target organ damage. Clin J Am Soc Nephrol 2006;1:221-228.

-9 Sica DA: Hyperkalemia risk in chronic kidney disease. Deterrent to the use of aldosterone receptor antagonism or not. Hypertension 2009;53:749-750.

10 Buczko W, Hermanowicz JM: Pharmacokinetics and pharmacodynamics of aliskiren, an oral direct renin inhibitor. Pharmacol Rep 2008;60:623-31.

-11 Rashikh A, Ahmaf SJ, Pillai KK, Najmi AK: Aliskiren as a novel therapeutic agent for hypertension and cardio-renal diseases. J Pharm Pharmacol 2011;64:470-481.

-12 Gradman AH, Schmieder RE, Lins RL, Nussberger J, Chiang Y, Bedigian MP: Aliskiren, a novel orally effective renin inhibitor, provides dose-dependent antihypertensive efficacy and placebo-like tolerability in hypertensive patients. Circulation 2005;111:1012-1018.

13 Campbell DJ: Interpretation of plasma renin concentration in patients receiving aliskiren therapy. Hypertension. 2008;51:15-18.

14 Siddiqi L, Oey PL, Blankestijn PJ: Aliskiren reduces sympathetic nerve activity and blood pressure in chronic kidney disease patients. Nephrol Dial Transplant 2011;26:2930-2934.

-15 Proudfoot JM, Croft KD, Puddey IB: Angiotensin II type 1 receptor antagonists inhibit basal as well as lowdensity lipoprotein and platelet-activating factor-stimulated human monocyte chemoattractant protein-1. J Pharmacol Exp Ther 2003;305:846-853.

-16 Kato S, Luyckx VA, Ots M, Lee KW, Ziai F, Troy JL, Brenner BM, MacKenzie HS: Renin-angiotensin blockade lowers MCP-1 expression in diabetes rats. Kidney Int 1999;56:1037-1048.

-17 Tone A, Shikata K, Ogawa D, Sasaki S, Nagase R, Sasaki M, Yozai K, Usui HK, Okada S, Wada J, Shikata Y, Makino H: Changes of gene expression profiles in macrophages stimulated by angiotensin II - Angiotensin II induced MCP-2 through AT1-receptor. JRAAS 2007;8:45-50.

-18 Andersen K, Weinberger MH, Constance CM, Ali MA, Jin J, Prescott MF, Keefe DL: Comparative effects of aliskiren-based and ramipril-based therapy on the renin system during long term (6-months) treatment and withdrawal in patients with hypertension. JRAAS 2009;10:157-167.

19 Karakousis K, Pinakas V, Kontovos I: Pleiotropic effect of aliskiren in reducing levels of hs-CRP and fibrinogen when added as treatment in patients previously in treatment with valsartan and amlodipine plus valsartan. J Hypertension 2010;28:391a.

20 Morishita Y, Hanawa S, Chinda J, Iimura O, Tsunematsu S, Kusano E: Effects of aliskiren on blood pressure and the predictive biomarkers for cardiovascular disease in hemodialysis-dependent chronic kidney disease patients with hypertension. Hypertens Res 2011;34:308-313.

21 Stanton A, Jensen Ch, Nussberger, O'Brien E: Blood pressure lowering in essential hypertension with an oral renin inhibitor aliskiren. Hypertension 2003;42:1137-1143. 


\section{Kidney \\ Blood Pressure Research}

Kidney Blood Press Res 2012;36:18-25

\begin{tabular}{l|l} 
DOI: $10.1159 / 000339023$ & C 2012 S. Karger AG, Basel
\end{tabular}

Published online: July 03, 2012

www.karger.com/kbr

-22 Parving HH, Persson F, Lewis JB, Lewis EJ, Hollenberg NK: AVOID Study Investigators. Aliskiren combined with losartan in type 2 diabetes and nephropathy. N Engl J Med 2008;358:2433-2446.

-23 Pool JL, Schmieder RE, Azizi M, Aldigier JC, Januszewicz A, Zidek W, Chiang Y, Satlin A: Aliskiren, an orally effective renin inhibitor, provides antihypertensive efficacy alone and in combination with valsartan. Am J Hypertens 2007;20:11-20.

-24 Oparil S, Yarows SA, Patel S, Fang H, Zhang J, Satlin A: Efficacy and safety of combined use of aliskiren and valsartan in patients with hypertension: a randomised, double-blind trial. Lancet 2007;370:221-229.

-25 Parving HH, Brenner BM, McMurray JJ, de Zeeuw D, Haffner SM, Solomon SD, Chaturvedi N, Ghadanfar M, Weissbach N, Xiang Z, Armbrecht J, Pfeffer MA: Aliskiren Trial in Type 2 Diabetes Using Cardio-Renal Endpoints (ALTITUDE): rationale and study design. Nephrol Dial Transplant 2009;24:1663-1671.

26 Morishita Y, Hanawa S, Chinda J, Iimura O, Tsunematsu S, Kusano E: Effects of aliskiren on blood pressure and the predictive biomarkers for cardiovascular disease in hemodialysis-dependent chronic kidney disease patients with hypertension. Hypertens Res 2011;34:308-313.

27 Azizi M, Ménard J: Renin Inhibitors and Cardiovascular and Renal Protection: An Endless Quest? Cardiovasc Drugs Ther 2012 :DOI 10.1007/s10557-012-6380-6386. [Epub ahead of print]

-28 Uresin Y, Taylor AA, Kilo CH: Efficacy and safety of the direct renin inhibitor aliskiren and ramipril alone or in combination in patients with diabetes and hypertension. JRAAS 2007;8:190-200.

29 Elijovich F, Laffer CL: Detrimental effects of dual ACEI-ARB therapy: is the (pro)renin receptor the culprit? Kidney Int 2011;80:911-914.

-30 Chandramohan G, Bai Y, Norris K, Rodriguez-Iturbe B, Vaziri ND: Effects of dietary salt on intrarenal angiotensin system, NAD(P)H oxidase, COX-2, MCP-1 and PAI-1 expression and NF-kB activity in salt sensitive and - resistant rat kidneys. Am J Nephrol 2008;28:158-167.

-31 Amann B, Tinzmann R, Angelkort B: ACE inhibitors improve diabetic nephropathy through suppression of renal MCP-1. Diabetes Care 2003;26:2421-2425.

32 Nguyen G, Muller DN: The biology of the (pro) renin receptor. J Am Soc Nephrol 201;21:18-23.

-33 Tang SCW, Lin ML, Tam S, Au WS, Ma MK, Yap DY, Ho YW, Lai KN: Aliskiren combined with losartan in immunoglobulin A nephropathy: an open-labeled pilot study. Nephrol Dial Transplant 2012;27:613-618.

34 Kang SH, Cho KH, Park JW, Park JW, Yoon KW, Do JY: Risk factors for mortality in stable peritoneal dialysis patients. Ren Fail 2012;34:149-154.

35 Sun CY, Cherng WJ, Jian HZ, Hsu HH, Wu IW, Hsu HJ, Wu MS: Aliskiren reduced renal fibrosis in mice with chronic ischemic kidney injury-beyond the direct renin inhibition. Hypertens Res 2012;35:304-311. 